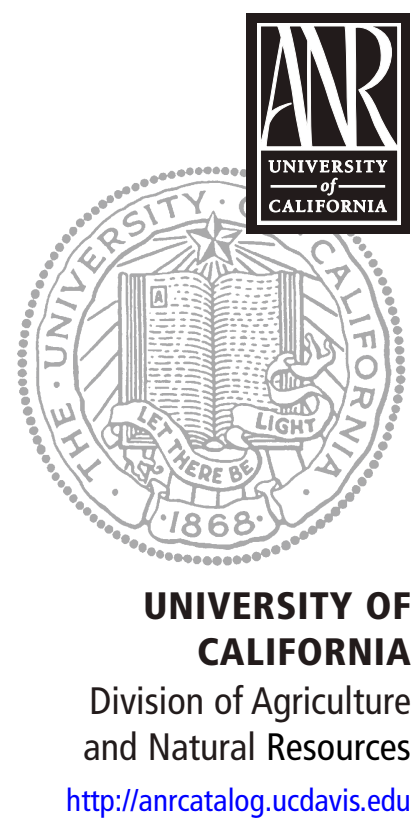

http://anrcatalog.ucdavis.edu

\title{
Patch Budding: A Convenient Method for Top-Working Olives
}

WILLIAM H. KRUEGER, Farm Advisor, University of California Cooperative Extension Glenn County; ZACHARY HEATH, and DOMINIC DELEONARDIS

ccasionally it may be desirable to change the variety of olive growing on an existing tree. This can be accomplished by top-working the existing tree (the "rootstock") to add the desired variety. Top-working has traditionally been done in California using the bark graft method, in which scion sticks are inserted into the cambial area between the bark and the wood of the rootstock (see Olive Production Manual, UC ANR Publication 3353; see also Propagation of Temperate-Zone Fruit Plants, UC ANR Publication 21103). The T-bud method of budding commonly used in other tree crops, while faster than patch budding, often results in bud failure in olives, possibly because the rootstock overgrows the buds. Additionally, T-budding is not suitable for larger limbs.

Patch budding can be used for top-working olives alone or in conjunction with bark grafting. In patch budding, a bark patch containing at least one dormant bud from the desired scion variety is secured to the cambium of the rootstock where a matching bark patch has been removed. Patch budding can be more desirable than bark grafting because

- Less scion material is required.

- It is faster and less expensive.

- It can be done during a longer time period.

- No tree seal is required.

- Damage from wood-boring insects is reduced.

The disadvantage of patch budding is that when it is done on larger limbs, vigorous new growth from patched buds may be more likely to break off.

\section{TIMING}

As with bark grafting, patch budding must be done when the bark "slips," or separates easily from the wood. Depending on seasonal climatic variation and limb size and position, olive bark should slip from the middle of March to the first of April until the end of August or September. The bark of smaller-diameter wood usually slips for a longer period than the bark of large scaffold limbs. The bark of vigorous small-diameter shoots may continue to slip into October and November. However, the slower growth rate at this time of year results in slower callus formation and poor bud take. For best results, patch budding should be completed by the end of August.

\section{SCION WOOD SELECTION}

Select vigorous 1- to 2-year-old growth about the diameter of a pencil or larger to supply buds for patch budding (fig. 1). If

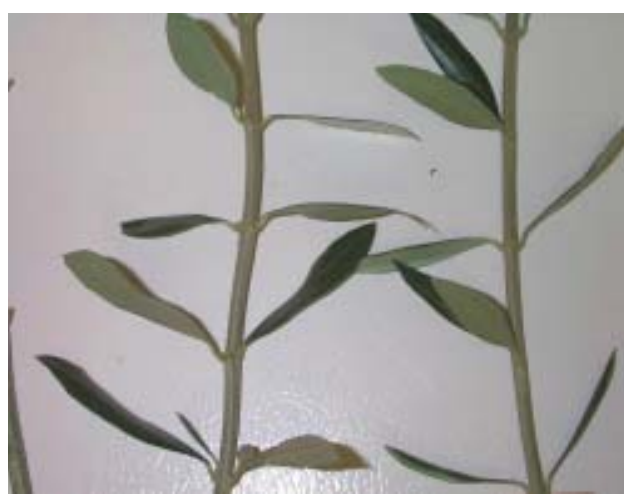

Figure 1. For best results when patch budding olives, select bud wood that is about the size of a pencil. Photo: Zachary Heath. 
buds will be patched onto large limbs, take the buds from large scion wood. Remove the leaves without damaging the buds. Place the bud wood on the rootstock as soon after collection as possible to prevent it from drying out. If longer storage is necessary, keep it in a bucket of water in the shade or in plastic bags in an ice chest.

\section{PATCH BUDDING SMALL TREES OR LIMBS}

When patch budding small trees or limbs, $3 / 8$ inch to 3 inches ( 1 to $7.5 \mathrm{~cm}$ ) in diameter, be careful not to remove too much bark from the rootstock when placing the patches. After removing patches, there should be a strip of bark on the rootstock at least $1 / 8$ inch $(3 \mathrm{~mm})$ wide to prevent the rootstock from being girdled. Cut the patches using a double-bladed budding knife with blades 3/4 to 1/4 (19 to $32 \mathrm{~mm}$ ) apart. A double-bladed knife can be made with two razor blades (see Propagation of TemperateZone Fruit Plants, UC ANR Publication 21103, pp. 21-22). The cuts can also be made with a single-bladed knife. To remove the patches, cut the bark of the scion above and below the two buds at the node. Using two buds as opposed to

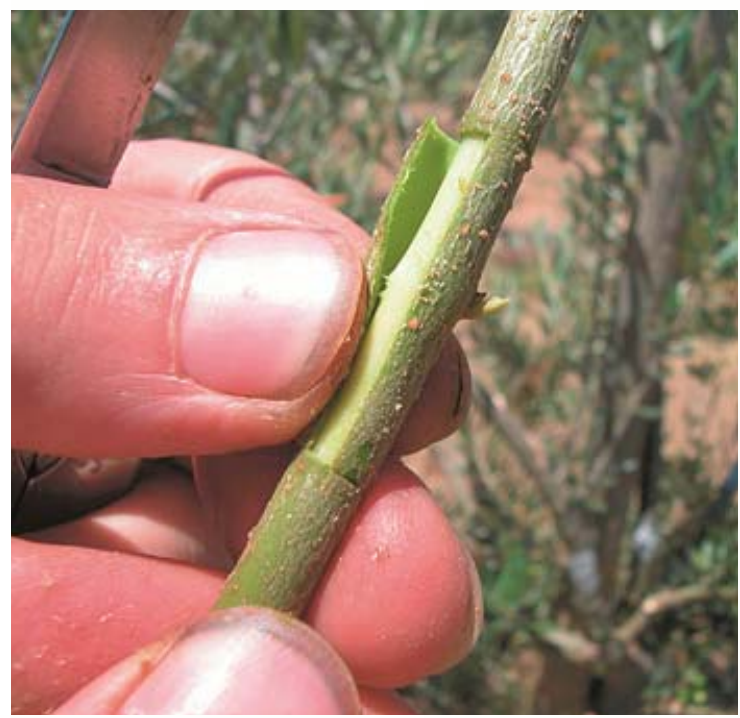

Figure 2. Remove the bud by slipping it sideways from the bud wood. This ensures that buds are removed with the bark patch and do not remain attached to the scion wood. Photo: William H. Krueger.

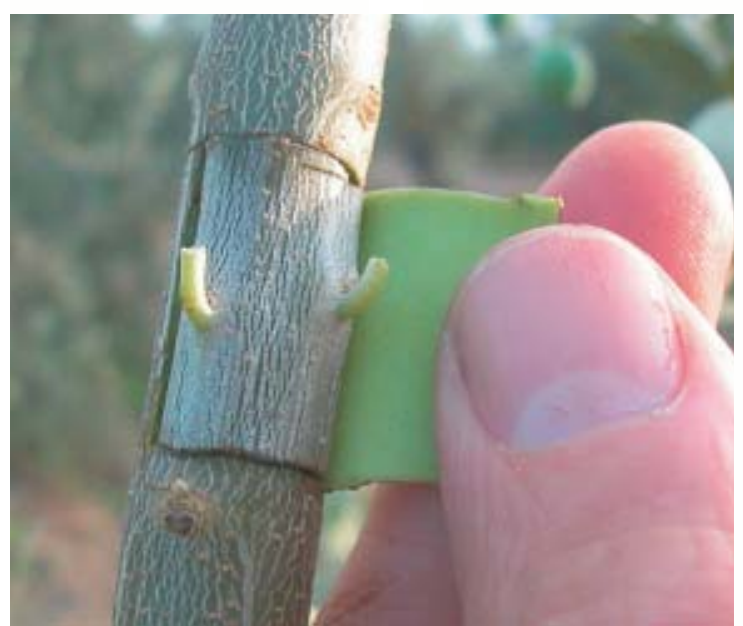

Figure 3. Peel back the bark from the rootstock and slip the bud into place. Photo: William H. Krueger. splitting the patch and using only one bud increases the chances of at least one bud growing successfully. Make a vertical cut between the two buds and slip the patch sideways to remove it from the scion (fig. 2). This prevents the buds from remaining attached to the scion wood. If bud wood is scarce or the rootstock shoot being budded is too small to accommodate the patch while leaving a strip of the original bark, cut the patch in half to make two smaller patches with a single bud in each.

Using the double-bladed knife, make two horizontal cuts on the rootstock, then make a vertical cut at one end of the horizontal cuts. Peel back the bark and slip the bud into place (fig. 3). Tear the bark even with the second vertical edge of the bud. The patch should fit snugly on the top and bottom. A small open space can be left along one side to keep the patch from buckling and losing cambial contact as the tree grows. Alternatively, one edge of the patch can be tucked under the rootstock bark on one side.

Tie the patch tightly to the tree. Cover all edges of the patch and leave the buds exposed (fig. 4). A wax-based budding tape is ideal for this purpose because it adheres to itself and does not have to be tied, secures the buds long enough for them to heal to the tree, and will stretch and break when the tree grows and does not have to be removed at a later date. Budding rubbers or plastic budding tape can also be used. Remove plastic tape after the buds are healed to avoid constricting the shoot.

Check the buds 2 to 3 weeks after placement; they should appear to be well healed, green, moist, and well attached to the rootstock. It may be possible to see callus tissue forming around the margin of the bud. If the buds have healed, force them to grow by cutting the limb directly above the new bud (see p. 4). If the budding was done late in the season (late July or August), it may be desirable to allow the bud to remain dormant until the next spring. 


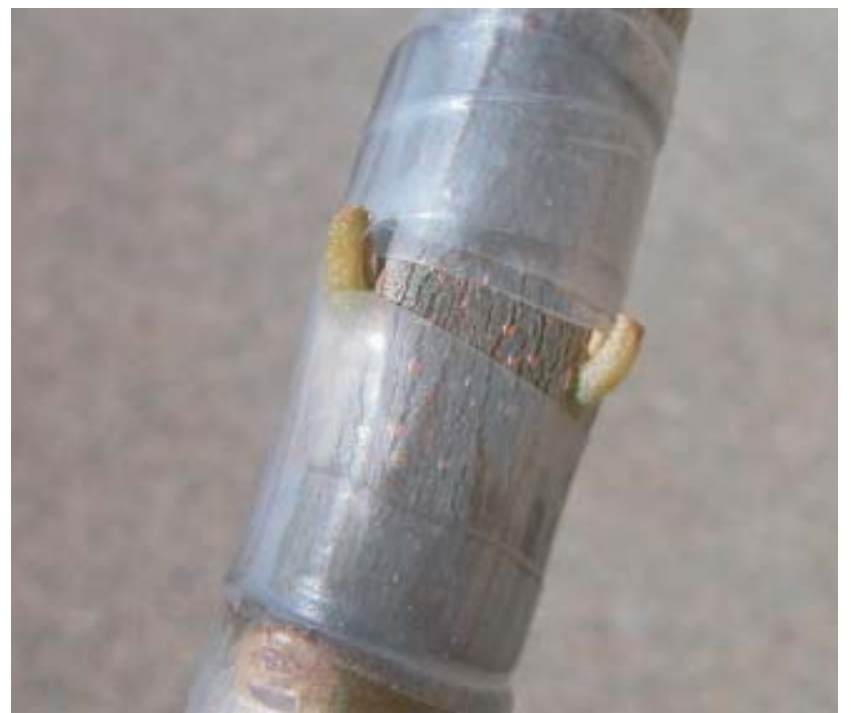

Figure 4. Secure the bud with wax-based budding tape. Bud rubbers or plastic budding tape can also be used. Photo: William $\mathrm{H}$. Krueger.

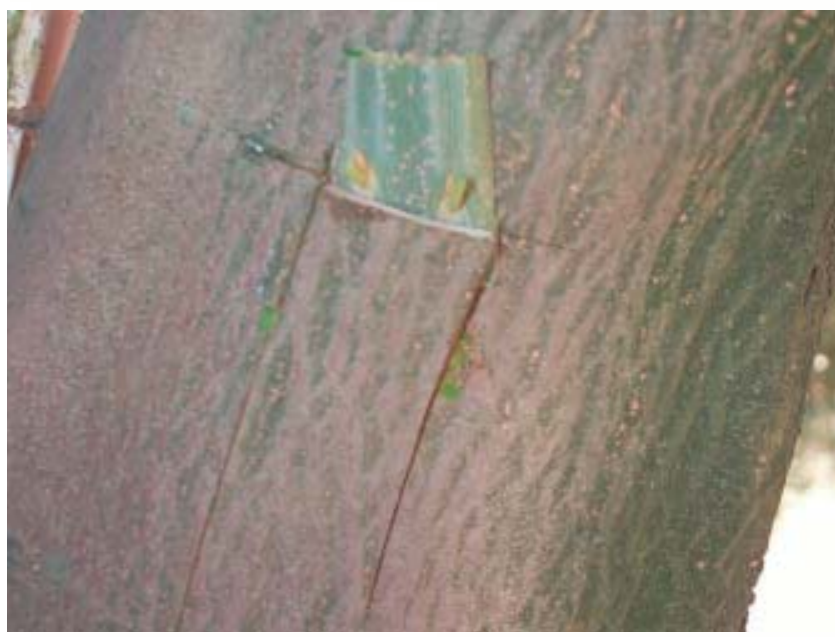

Figure 5. When patch budding large trees, insert the bud under the rootstock's bark to help hold the bud in place. Photo: William $\mathrm{H}$. Krueger.

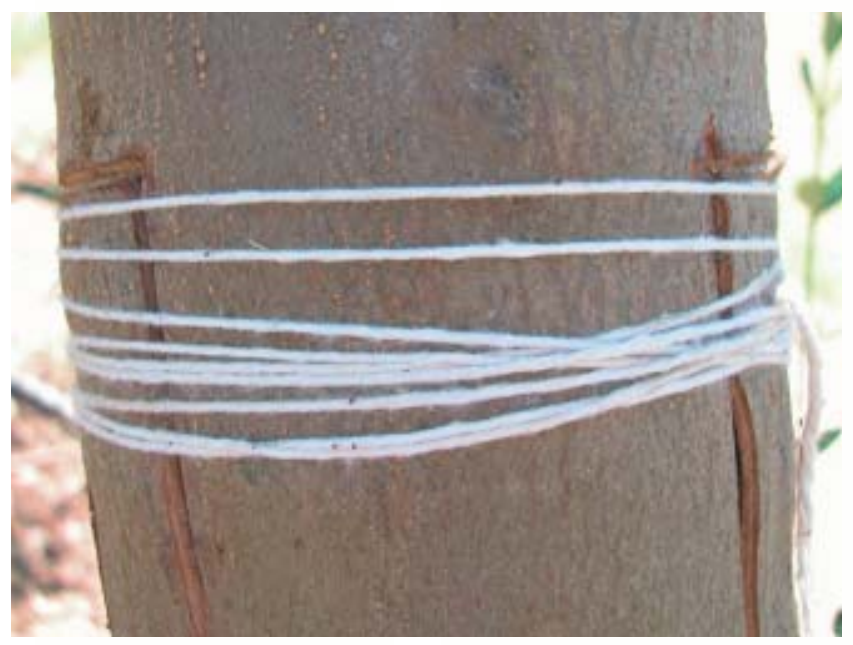

Figure 6. Secure patch buds on large trees by wrapping the buds with string. Photo: William H. Krueger.

\section{PATCH BUDDING LARGER TREES}

While patch budding is more commonly used on smaller trees, it can be successfully used, with certain adaptations, on larger trees with scaffold limbs 6 inches $(15 \mathrm{~cm})$ or greater in diameter.

One problem when patch budding larger trees is that the bark of the rootstock is much thicker than the bark of the scion, making it difficult to ensure adequate contact of the cambial layers to allow the patched bud to heal. One way of overcoming this limitation is to use the bark from the rootstock to hold the patch in place. To do this, remove the patch from the scion as described above. With larger limbs it is helpful to use larger patches, buds cut from branches $1 / 2$ inch $(1.3 \mathrm{~cm})$ in diameter or greater. In some cases, it may be desirable to use buds from 2-year-old growth. Hold the patch on the limb where the bud is to be placed and cut through the bark of the limb to be grafted on the sides and top of the bud. The side cuts should be wide enough to accommodate the patch while leaving a small open space on one side of the bud to prevent the bud from buckling and losing cambial contact. Pry up the bark flap and slip the bud under the bark (fig. 5). Push the patch down until the top of the patch is even with the top cut on the rootstock. Place a bud every 3 to 5 inches $(7.5$ to $12.5 \mathrm{~cm}$ ) around the limb at the same height on the branch. (This spacing is similar to bud stick spacing in bark grafting.) Secure the buds by tightly wrapping a piece of twine several times around the limb (fig. 6). The twine should press the bark flaps to the buds and hold them in place.

Using bark from the rootstock to hold the bud in place is generally easier and more successful on smooth-barked limbs than on older limbs with cracked or fissured bark. This is probably because the smooth bark is more pliable and conforms more easily to the bud. Thin old, fissured bark by removing the outer layer of the bark with a knife before inserting the bud. This leaves the more pliable inner bark, which conforms more easily to the bud.

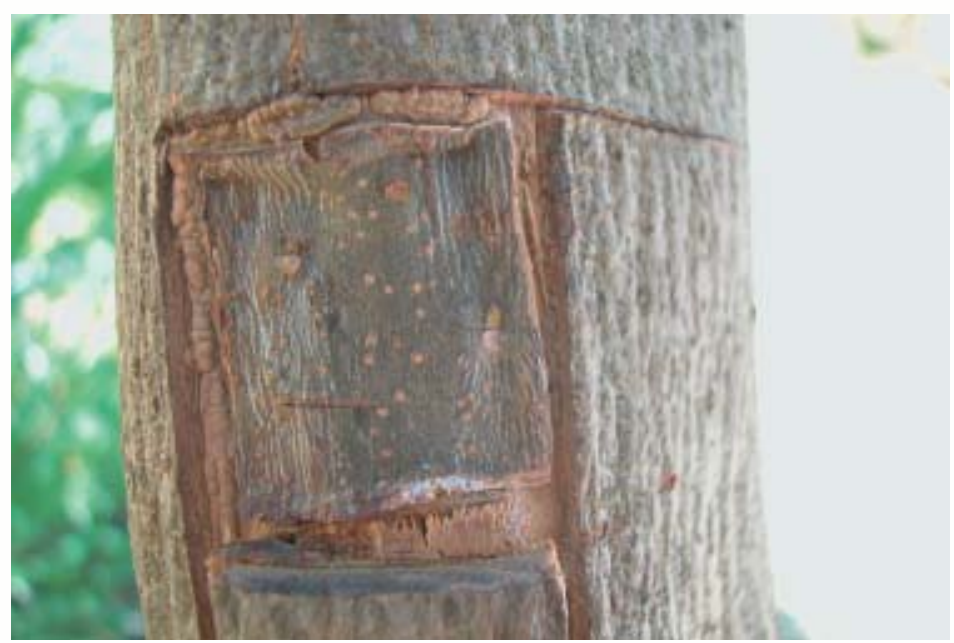

Figure 7. Healed patch in a somewhat larger tree 1 to 2 months after placement. Photo: Zachary Heath. 
Buds take longer to heal on larger limbs than they do on smaller limbs: 1 month appears to be the minimum, and it is often best to wait longer before forcing the buds. After 1 month, remove some of the ties and inspect the buds. If the buds appear to be healthy and well healed (fig. 7), remove the rootstock limb just above the new buds to force the buds to grow. Buds can also be forced by girdling the trunk (removing a strip of bark) just above the inserted bud (fig. 8). The time required for the buds to heal before forcing may not allow adequate time for sufficient growth to occur before the end of favorable growing conditions. If the buds are forced too soon, their survival rate may be reduced. An alternative to forcing the buds the same year is to allow them to remain dormant for the rest of the season. This allows a long budding window (easily from May through August) and can result in a higher survival rate, especially compared to forcing the buds too early during the year they are placed.

The ties and bark flap can be removed after the bud has healed well. They should be removed within 2 months so that the bark flap does not overgrow the bud. To remove the bark flap, cut and remove the twine, then cut through the bark flap at the bottom of the patch and remove it, taking care not to expose the cambium below the bud.

As with other types of topworking, leave one or two scaffolds on the south side of the tree to serve as "nurse limbs" to help maintain the root system (fig. 9). The nurse limbs are normally removed after 1 or 2 years when the buds have made adequate growth.

One drawback to budding larger limbs is the risk that the new shoots will break off before they are adequately supported by the rootstock. Buds grow very rapidly, and their new growth can quickly become quite large. This new growth is secured to the tree only by the new wood that grows under and around the bud. Because of this weak connection, the new growth may break off. However, if several buds were patched, enough of them will usually survive to make up for the ones that are lost. The risk of breaking can be reduced by pruning the tips of the new shoots to stiffen them and slow their growth, or by tying the new shoots to sticks or lath nailed to the tree.

\section{FOLLOW-UP CARE}

After the buds begin to grow, remove competing buds that sprout below the new buds to encourage the new buds to grow. Competing buds may need to be removed several

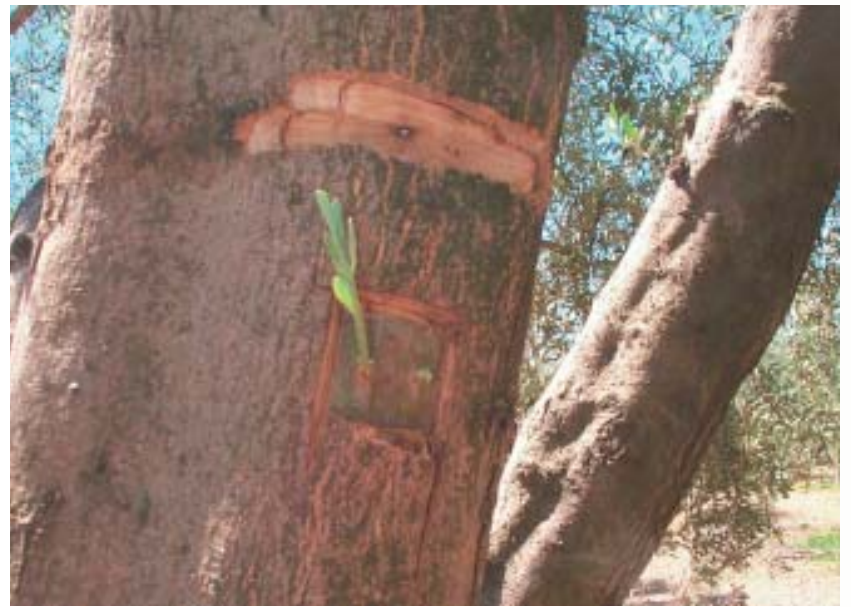

Figure 8. Girdling the limb just above the patch bud forces the bud to grow. Photo: William H. Krueger.

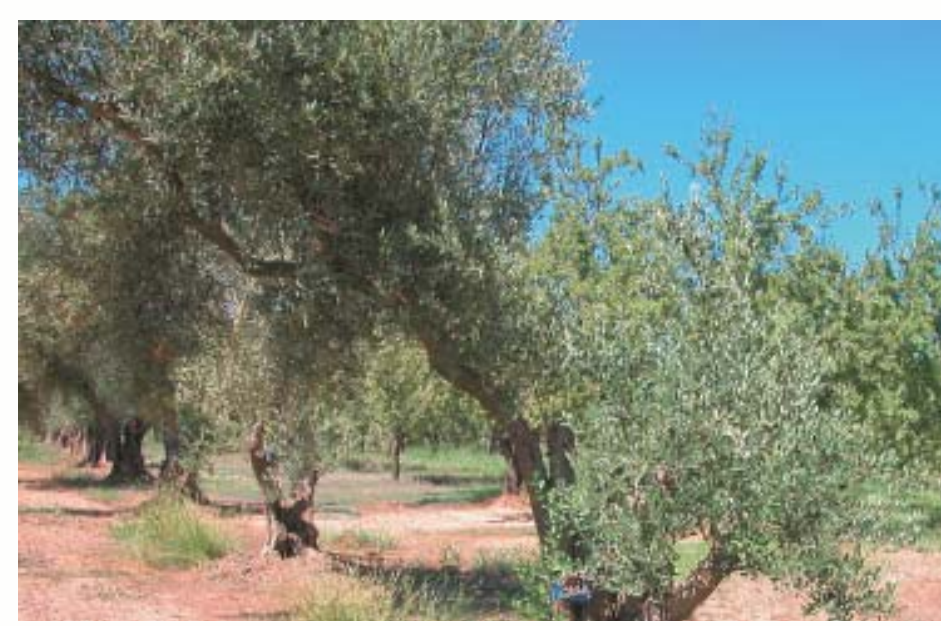

Figure 9. Retain one or two scaffold branches on the south side of a budded tree to act as nurse limbs. Remove nurse limbs after 1 or 2 years. Photo: William H. Krueger. 
times the first and second seasons. If these buds are not removed, their growth will outcompete the patched buds and limit their growth.

Although much less problematic than with bark grafts, patch buds should be watched for infestation by American plum borer (Euzophera semifuneralis), whose larvae feed on the callus tissue that heals the patch to the rootstock. Their presence is indicated by frass (reddish, sawdustlike fecal material) at the base of the patched buds. Plum borer feeding can threaten the survival of the new shoots. Additionally, the new growth from the buds may be damaged by feeding from weevil species, including the cribrate weevil (Otiorhynchus cribricollis). These nocturnal feeders cause a characteristic notching of the leaves. Feeding damage on mature trees is normally of little consequence. However, because feeding damage is normally concentrated on the lower part of the tree where the buds are located, the buds may be stunted or even killed. Watch the buds for damage from these or other insects and, if noticed, treat with a registered insecticide (see UC IPM Pest Management Guidelines: Olive, ANR Publication 3452).

\section{FOR MORE INFORMATION}

You'll find more information on planting and care of olive trees in the following ANR products:

Olive Production Manual, UC ANR Publication 3353, 1994.

Propagation of Temperate-Zone Fruit Plants, UC ANR Publication 21103, 1994.

UC IPM Pest Management Guidelines: Olive, ANR Publication 3452, 2002, available

for free downloading from the UC IPM Web site at

http://www.ipm.ucdavis.edu/PMG/selectnewpest.olives.html\#INSECTS.

Visit our online catalog at http://anrcatalog.ucdavis.edu. You can also place orders by mail, phone, or FAX, or request a printed catalog of publications, slide sets, CD-

ROMs and videos from

University of California

Agriculture and Natural Resources

Communication Services

6701 San Pablo Avenue, 2nd Floor

Oakland, California 94608-1239

Telephone: (800) 994-8849 or (510) 642-2431; FAX: (510) 643-5470

E-mail inquiries: danrcs@ucdavis.edu

An electronic version of this publication is available on the ANR Communication Services Web site at http://anrcatalog.ucdavis.edu.

\section{Publication 8115}

(C) 2004 by the Regents of the University of California, Division of Agriculture and Natural Resources. All rights reserved.

The University of California prohibits discrimination against or harassment of any person employed by or seeking employment with the University on the basis of race, color, national origin, religion, sex, physical or mental disability, medical condition (cancer-related or genetic characteristics), ancestry, marital status, age, sexual orientation, citizenship, or status as a covered veteran (special disabled veteran, Vietnam-era veteran or any other veteran who served on active duty during a war or in a campaign or expedition for which a campaign badge has been authorized). University Policy is intended to be consistent with the provisions of applicable State and Federal laws. 
Inquiries regarding the University's nondiscrimination policies may be directed to the Affirmative Action/Staff Personnel Services Director, University of California, Agriculture and Natural Resources, 300 Lakeside Drive, 6th Floor, Oakland, CA 94612-3550 (510) 987-0096. For a free catalog of other publications, call (800) 994-8849. For help downloading this publication, call (530) 754-5112.

pr-1/04-SB/CR

ISBN 978-1-60107-294-8

This publication has been anonymously peer reviewed for technical accuracy by University of California scientists and other qualified professionals. This review process was managed by the ANR Associate Editor for Pomology, Viticulture, and Subtropical Horticulture. 